\title{
Modulation of pro- and anti-apoptotic factors in human melanoma cells exposed to histone deacetylase inhibitors
}

\author{
F. Facchetti, S. Previdi, M. Ballarini, S. Minucci, P. Perego and C. A. M. La Porta \\ Department of Biomolecular Sciences and Biotechnology, University of Milan, Italy (F. Facchetti, S. Previdi, S. Minucci, \\ C. A. M. La Porta); European Institute of Oncology (IEO) (M. Ballarini, S. Minucci), National Cancer Institute, Milan, Italy \\ (P. Perego)
}

\begin{abstract}
Valproic acid (VPA, 2-propylpentanoic acid) is an established drug in the long-term therapy of epilepsy. Recently, VPA was demonstrated to inhibit histone deacetylases (HDACs) class I enzyme at therapeutically relevant concentrations, thereby, mimicking the prototypical histone deacetylase inhibitors, tricostatin A (TSA) or suberoylanilide hydroxamic acid (SAHA). In the present study, we investigated the cellular effects of VPA, TSA and SAHA on four human melanoma cell lines (WM115, WM266, A375, SK-Mel28) with particular reference to the modulation of regulators of apoptosis, including $\mathrm{Bcl}-2, \mathrm{BcIXL}$, Mcl-1, Apaf-1, BcIXs, NOXA, TRAIL-R1, TRAIL-R2, caspase 8 , and survivin). Firstly, we found that VPA induced apoptosis in two of the four human melanoma cell lines, while both TSA and SAHA exhibited an antiproliferative and apoptotic effects in all four cell lines, a different expression of $\mathrm{Bcl}-2$ and $\mathrm{Bcl} \mathrm{X}_{\mathrm{L} / \mathrm{s}}$ occurred. On the other hand, SAHA and VPA modulated differently pro- and antiapoptotic factors. In particular, the treatment with VPA enhanced the level of expression of survivin only in VPAresistant cell lines, whereas down-regulation of survivin was induced by VPA and SAHA in VPA-sensitive cells. In the latter, since activation of caspase 8 was documented, a receptor-mediated apoptosis was suggested. Taken together, our results suggest that HDAC inhibitors may represent a promising therapeutic strategy to treat melanoma.
\end{abstract}

Keywords: BcIX/Bcl2; melanoma; SAHA; survivin;TRAIL; valproic acid.

\section{Introduction}

The structure of chromatin may be altered by posttranslational modifications such as acetylation which play a role in regulating gene expression. Two groups of enzymes, histone deacetylase (HDACs) and histone acetyl-

Correspondence to: Caterina A. M. La Porta, Department of Biomolecular Sciences and Biotechnology, University of Milan, Celoria 26, 20133 Milan. Italy. Tel: +39-02-50314926; Fax: +390250314932; e-mail: caterina.laporta@unimi.it transferases (HATs), determine the acetylation status of histones. HDACs catalyse the removal of acetyl groups from lysine residues in the amino-terminal tails of the nucleosomal core histones. ${ }^{1,2}$ There are three classes of HDACs, class I (HDACs 1, 2, 3 and 8), class II (HDACs 4, 5, 6, 7, 9 and 10) and class III. The latter is structurally distant with respect to the others and is not inhibited by HDAC inhibitors for classes I/II, often characterized by a hydroxamic acid moiety. ${ }^{3,4}$ Alterations in the acetylation levels of chromatin and deregulated function of HDACs have been involved in tumorigenesis. ${ }^{5}$ Several HDAC inhibitors are currently in clinical trials as anticancer agents since they show an inhibitory activity against cancer at well-tolerated doses. ${ }^{6}$

Valproic acid (VPA, 2-propylpentanoic acid) is an established drug in the long-term therapy of epilepsy. Although VPA is well tolerated by patients, it can induce birth defects such as neural tube closure and other malformations, if administered during early pregnancy. ${ }^{7,8}$ The mechanism responsible for such defects is at yet unclear. ${ }^{9}$ Recently, VPA was demonstrated to inhibit corepressorassociated HDACs, acting on class I more efficiently than class II enzymes at therapeutically relevant concentrations mimicking the prototypical histone deacetylase inhibitor, tricostatine. ${ }^{10,11}$ Furthermore, VPA acts as a potent inducer of differentiation in several types of transformed cells. ${ }^{10}$ VPA shows mild adverse effects in adults even if serum levels exceed the normal therapeutic range during antiepileptic therapy. ${ }^{10}$ In addition, the daily doses of VPA required to achieve therapeutic serum levels in patients $(20-30 \mathrm{mg} / \mathrm{Kg}$ ) are moderate in comparison with those required for other available inhibitors such as butyrate or suberoylanilide hydroxamic acid (SAHA). ${ }^{2,12}$ Since VPA is a well-tolerate drug even during long-term treatment, it has been recently proposed as a useful drug in cancer therapy. ${ }^{10}$ The mild side effects, mostly on the central nervous system, may be reduced with appropriate modification of the VPA molecule as demonstrated by S-4-yn-VPA or derivates with longer side chains. ${ }^{13}$ In particular, such 
a drug appears promising as low toxicity agent given over long time periods for chemoprevention and/or for control of residual minimal disease. ${ }^{14}$

The main goal of the present study was to investigate the effects of the treatment with VPA or other HDAC inhibitors (SAHA and TSA) on several human melanoma cell lines (WM115, WM266, A375, SK-Mel28). We observed in several-but not all-cases the induction of apoptosis by the treatment with HDAC inhibitors. Thereby, herein, we investigated the expression of antior pro-apoptocic factors following treatment (exemplified by Bcl-2, BclX $\mathrm{L}$, Mcl-1, Apaf-1, BclXs, NOXA, Mcl-1 and survivin). In this context, since tumor necrosis factor (TNF) related apoptosis inducing ligand (TRAIL), a member of the TNF family, can induce apoptosis in melanoma cells depending on the levels of surface expression of the death receptors, particularly TRAIL-R2, ${ }^{15}$ the possible involvement of TRAIL-R1 and -R2 in the observed apoptosis was also investigated.

Our findings show for the first time that distinct human melanoma cell lines present a different balance in the expression of pro- and anti-apoptotic factors either at the basal level and following exposure to HDAC inhibitors. Interestingly, HDAC inhibitors modulate survivin expression in a different ways in distinct cell lines.

\section{Materials and methods}

\section{Cell lines, treatments and reagents}

Human WM115, SK-Mel28, WM266 and A375 cells were purchased from ATCC and maintained under the following conditions: WM266, SK-Mel28 and A375 in DMEM medium; WM266 in MEM and WM115 in BME medium. Cells cultured in DMEM or MEM medium were supplemented with $10 \%$ fetal calf serum, $2 \%$ MEM vitamin, $1 \%$ non essential aminoacids, $1 \%$ antibiotics/antimicotics (100 U/ml pennicillin, $100 \mu \mathrm{g} / \mathrm{ml}$ streptomycin, $0.25 \mu \mathrm{g} / \mathrm{ml}$ amphotericine) while cells cultured in BME medium were supplemented with $10 \%$ fetal calf serum, $2 \%$ BME vitamin, $1 \%$ non essential aminoacids, $1 \%$ antibiotics/antimicotics $(100 \mathrm{U} / \mathrm{ml}$ pennicillin, $100 \mu \mathrm{g} / \mathrm{ml}$ streptomycin, $0.25 \mu \mathrm{g} / \mathrm{ml}$ amphotericine). All the cells were grown at $37^{\circ} \mathrm{C}$ and $5 \% \mathrm{CO}_{2}$.

A fixed number of cells (as reported in the legend of figurers) were plated on 96-well plates and $24 \mathrm{~h}$ after plating cells were treated with $1 \mathrm{mM}$ VPA for 1 week or with $100 \mathrm{ng} / \mathrm{ml}$ tricostatine (TSA) or with SAHA $(4 \mu \mathrm{M})$ for $72 \mathrm{~h}$. At the end of the treatments the proliferative rate of the cells were measured by the MTT (thiazolyl blue) assay.

As positive control, exponentially growing Jurkat cells were treated with anti-Fas antibody $(1 \mu \mathrm{g} / \mathrm{ml} ; \mathrm{mAB}$ clone APO 1-3 Kamya Biomedical Co.) for $24 \mathrm{~h}$ to activate caspase 8 and therefore Fas-mediated apoptosis (90\% apop- tosis, data not shown). At the end of the treatment the cells were processed for Western blot analysis.

\section{Cell cycle analysis}

To assess the percentage of cells in different cell cycle phases, including cells with a subG1 DNA content (apoptotic cells), cell cycle analysis was carried out. Subconfluent cells were fixed in iced ethanol and kept at $4^{\circ} \mathrm{C}$ until staining for the cytofluorimetric analysis. The fixed cells were washed once with $1 \mathrm{ml}$ phosphate-buffered saline (PBS) containing 1\% BSA and then incubated with PBS containing $6.25 \mu \mathrm{g} / \mathrm{ml}$ RNAse (Sigma. St Louis, MO) and $50 \mu \mathrm{g} / \mathrm{ml}$ of propidium iodide (PI) overnight at $4^{\circ} \mathrm{C}$ to stain DNA. Cells were acquired with a FACSscanplus (Becton-Dickinson) equipped with an argon-ion laser (excitation wavelength $488 \mathrm{~nm}$, laser power $200 \mathrm{~mW}$ ). The sample flow rate during analysis did not exceed 500-600 cells/s. Typically 30000 cells were analysed per sample. DNA deconvolutions were carried out using the software program CELLQUEST (Becton-Dickinson). The experiments were repeated at least four times.

\section{Western blot analysis}

Whole cells lysates were prepared suspending the cell pellets in lysis buffer containing $20 \mathrm{mM}$ TRIS-HCl, pH7.5, 12 mM EDTA, $0.5 \mathrm{mM}$ EGTA, $5 \mu \mathrm{M}$ leupeptin, $0.15 \mu \mathrm{M}$ pepstatin A, $0.5 \mathrm{mM}$ PMSF and $1 \%$ Triton-X100, homogenized at $4^{\circ} \mathrm{C}$. The protein content was evaluated using Lowry method. ${ }^{16}$ The cells lysates were mixed with $2 \mathrm{X}$ sodium dodecyl sulphate (SDS)containing buffer and loaded in polyacrylamide gels (SDSPAGE) according to literature method, ${ }^{17}$ and transferred to PVDF sheet overnight. ${ }^{18}$ The sheets were incubated overnight with anti-Bcl2 (1:100 Dako) or anti-BclX $\mathrm{L} / \mathrm{S}$ (1:2000, Pharmingen) or anti-Apaf-1 (1:1000, Sigma) or anti-human caspase 8 (1:2000, Kamya Biomedical Co) at $4^{\circ} \mathrm{C}$. The signal was developed with ECL-Plus (Amersham-Biotech) according to the manufacturers instructions. Equal loading of protein on the gel was verified by $10 \%$ SDS-PAGE and stained with Coomassie Brilliant Blue R250. Furthermore, to check the correct loading of the samples, the sheet was incubated with anti- $\beta$ actin antibody (1:1000; Sigma). The molecular weights were estimated using prestained markers. The results were analysed by densitometric analysis using ImageMaster software (Pharmacia Biotech).

\section{Determination of Histone $\mathrm{H} 3$ and $\mathrm{H} 4$ acetylation status}

Accumulation of hyperacetylated histones $\mathrm{H} 3$ and $\mathrm{H} 4$ was analysed in cell lysates by western blotting using 
antibodies directed against acetylated histones $\mathrm{H} 3$ and H4 (1:1000, UpState) or only against non acetylated hystone $\mathrm{H} 4$ (1:1000, UpState). Whole-cell lysates were prepared in denaturating SDS sample buffer and separated on $15 \%$ SDS-polyacrylamide gels. Equal loading was confirmed incubating the sheet with anti-non acetylated H4.

\section{RT-PCR}

Total RNA was prepared from subconfluent cells using the RNeasy Mini Kit from Qiagen. One microgram of total RNA was reverse-transcribed and amplified by means of an "Enhanced avian hs RT-PCR" (Sigma) according to the manufacturer's instructions. PCR was performed at $93^{\circ} \mathrm{C}$ for $5 \mathrm{~min}$ (first denaturation) and then 35 cycles were run at $93^{\circ} \mathrm{C}$ for $1 \mathrm{~min}$ (denaturation), $52^{\circ} \mathrm{C}$ for $1.30 \mathrm{~min}$ (annealing) and $72^{\circ} \mathrm{C}$ for $1 \mathrm{~min}$ (extension) for TRAIL-R 1 and $\mathrm{R} 2 ; 95^{\circ} \mathrm{C}$ for $10 \mathrm{~min}$ (first denaturation); 40 cycles were run at $95^{\circ} \mathrm{C}$ for $30 \mathrm{sec}$ (denaturation), $55^{\circ} \mathrm{C}$ for $15 \mathrm{sec}$ (annealing) and $72^{\circ} \mathrm{C}$ for $30 \mathrm{sec}$ (extension) for survivin and NOXA; 40 cycles were run for Mcl-1 at $95^{\circ} \mathrm{C}$ (first denaturation) $30 \mathrm{sec}$, $61^{\circ} \mathrm{C}$ (annealing) $15 \mathrm{sec}$ and $72^{\circ} \mathrm{C} 30 \mathrm{sec}$ (extension). The final extension was $10 \mathrm{~min}$ at $72^{\circ} \mathrm{C}$. PCR products were analysed by agarose gel $(1.5 \%)$ electrophoresis and photographed under UV light. Nucleotide sequences of PCR primers were: TRAIL-R1-sense5'CGATGTGGTCAGAGCTGGTACAGC- $3^{\prime}$ and antinsense-5'-GGACACGGCAGAGCCTGTGCCAT C-3', 217 bp amplified fragment; TRAIL-R2-sense5'-GGGAGCCGCTCATGAGGAAGTTGG- $3^{\prime}$ and antisense-5'GGCAAGTCTCTCTCCCAGCGT CTC-3', 182 bp amplified product; ${ }^{19}$ survivin-sense $5^{\prime}$ AAGAACTGGCCCTTCTTGGA- $3^{\prime}$ and antisense- $5^{\prime}$ CAACCGGACGAATGCTTTTT-3', 147 bp amplified fragment; ${ }^{20}$ NOXA- sense- 5'GTCCGAGGTGCTCCAGTT- $3^{\prime}$ and antisense-5' AAACGTGCACTCCCTGAGA-3' (external primers) and sense- ${ }^{\prime}$-GGGCTCTGTCGCTGAG- $3^{\prime}$ and antisense- ${ }^{\prime}$-TCGACCTCCTGAGAAAACT- $3^{\prime}$ (internal primers) 226 bp amplified fragment; ${ }^{21}$ Mcl-1-sense-5'CACGAGACGGTCTTCCAAGGCATGCT- $3^{\prime}$ and antisense- $5^{\prime}$-CTAGGTTGCTAGGGTGCAACTCT AGGA-3', 496 bp amplified product. GAPDH was used as housekeeping gene to control for loading.

\section{Statistics}

The ANOVA one-way test was used to determine statistical significance. A $P$ value of less than 0.05 was considered to be statistically significant.
Table 1. Cell cycle analysis

\begin{tabular}{lccc}
\hline & control & $\begin{array}{c}+ \text { VPA } \\
1 \mathrm{mM} / 1 \text { week }\end{array}$ & $\begin{array}{c}+ \text { TSA } \\
100 \mathrm{ng} / \mathrm{ml} \text { 1 week }\end{array}$ \\
\hline A375 & & & \\
$\%$ G1 & 76 & 64 & - \\
$\%$ apoptosis & 20 & 73 & 96 \\
SK-Mel28 & & & \\
$\%$ G1 & 32 & 30 & 42 \\
$\%$ apoptosis & 8 & 8 & 45 \\
\hline
\end{tabular}

Subconfluent cells $\left(10^{6}\right)$ untreated or treated with VPA or TSA, were trypsinized, fixed in ethanol and stained with $\mathrm{PI}(50 \mathrm{mg} / \mathrm{ml})$ as described in the Materials and Method section. DNA deconvolutions have been carried out using the software program CELLQUEST (Beclon-Dickinson).

The Tables shows the percentage of cells in $\mathrm{G} 1$ or in pre-G1 (apoptotic).

\section{Results}

\section{Effect of VPA on the proliferation of four human melanoma cell lines}

We have compared the effect of three HDAC inhibitors (VPA, SAHA and TSA) on four human melanoma cell lines, that is, WM115 (derived from primary melanoma), WM266 (from metastatic melanoma), A375 (an amelanotyc cell line) and SK-Mel28 (a melanotyic cell line from metastatic melanoma). In two out of four cell lines, VPA inhibited the proliferation (65 and 33\% for WM266 and A375, respectively), while SK-Mel28 and WM115 human melanoma cells were resistant to VPA treatment (Figure 1). Cytofluorimentric analyses supported that the inhibition of proliferation was associated with induction of apoptosis, as shown by appearance of cells with subG1 DNA content after drug exposure (Table 1). Since a shortterm incubation with VPA was less efficient (data not shown), in all the experiments the cells were exposed to $1 \mathrm{mM}$ VPA for a week. In contrast, TSA $(72 \mathrm{~h}, 0.1 \mu \mathrm{g} / \mathrm{ml})$ or SAHA ( 4 or $8 \mu \mathrm{M}, 72 \mathrm{~h}$ ) treatments inhibited all the analysed cell lines, leading to apoptosis (Figure 1 and Table 1).

\section{Analysis of hystone $\mathrm{H} 3$ and $\mathrm{H} 4$ acetylation}

To examine the interference of the studied HDAC inhibitors with their target, we performed Western blot analysis of the acetylation status of $\mathrm{H} 3$ and $\mathrm{H} 4$ histones. Since in all the four human melanoma cell lines we obtained similar results, in Figure 2 a typical experiment. The status of acetylation of hystone $\mathrm{H} 3$ and $\mathrm{H} 4$ increased after the treatment with VPA $(1 \mathrm{mM})$ as well as after TSA $(100 \mathrm{ng} / \mathrm{ml})$ or SAHA treatments $(4 \mu \mathrm{M})$ (Figure 2, Panel A and B). We, therefore, can exclude that the differential effects of VPA versus the other HDAC inhibitors in 
Figure 1. Cells were plated into 96-well plates $(500,1000,4000$ and 5000 cells/well for WM115, A375, SKMel28 and WM266, respectively). $24 \mathrm{~h}$ later the cells were incubated with $100 \mathrm{ng} / \mathrm{ml}$ TSA, $4 \mu \mathrm{M}$ SAHA or $8 \mu \mathrm{M}$ SAHA for $72 \mathrm{~h}$ or with $1 \mathrm{mM}$ VPA for a week. At the end of the treatments the proliferative rate was evaluated using MTT-assay as described in the Materials and Methods section. The results are expressed as percentage of cells with respect to untreated control cells. The values represent the means \pm SE of at least three independent experiments. ${ }^{* * *}, p<0.001$ vs. untreated cells.
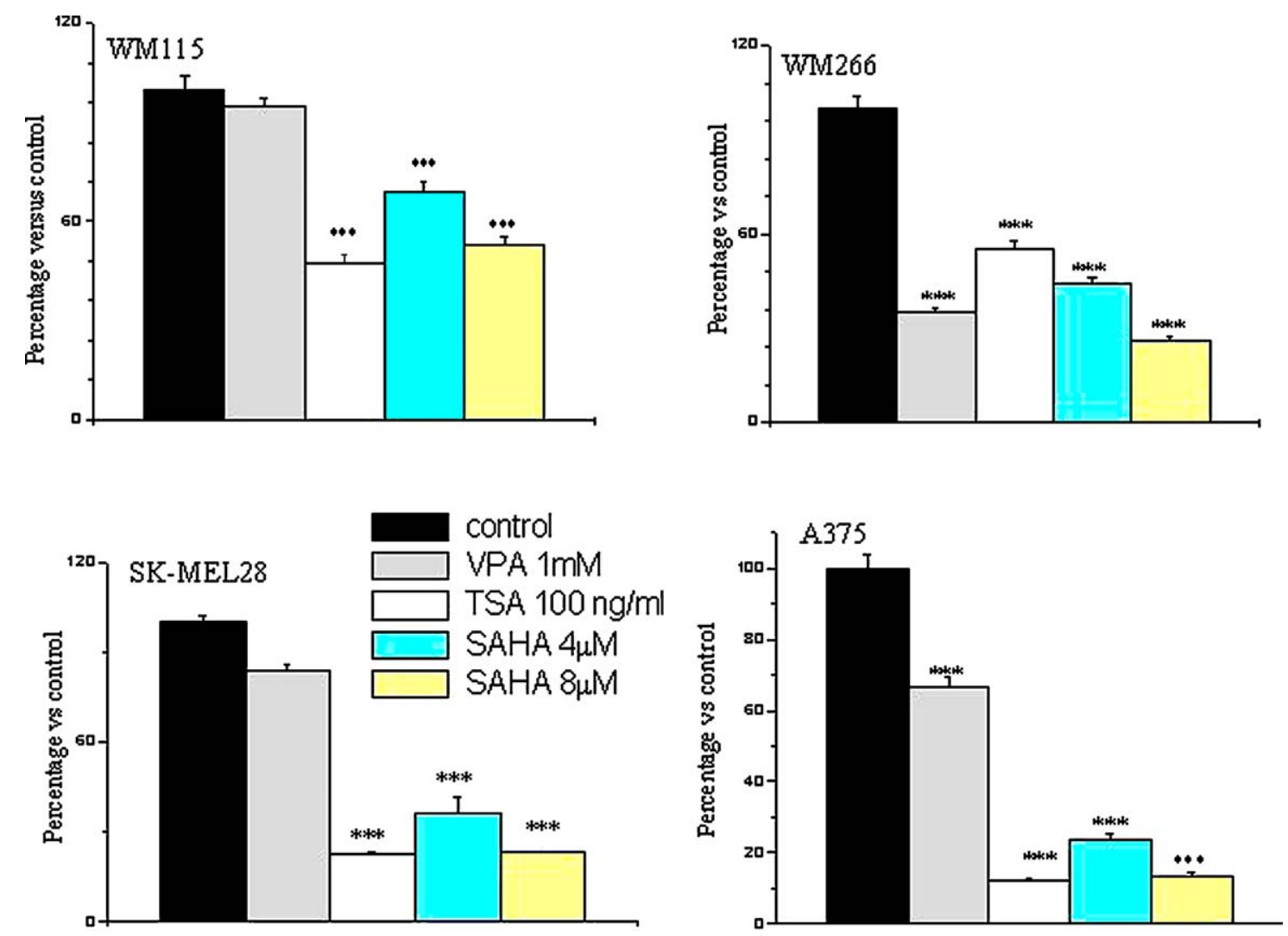

Figure 2. Subconfluent cells treated with $5 \mathrm{ng} / \mathrm{ml}$ TSA or $1 \mu \mathrm{M}$ SAHA for $72 \mathrm{~h}$ or with $1 \mathrm{mM}$ VPA for a week were harvested by tripsinization and collected by centrifugation. Cellular pellets were resuspended in sample buffer of Laemmli and boiled for 5 minutes. A fixed number of cells $\left(5 \cdot 10^{5}\right.$ cells) for each treatment were submitted to $15 \%$ SDS-PAGE and blotted onto a PVDF sheet. The membrane was incubated with anti-H3 (1:1000, UpState) or $\mathrm{H} 4$ (1:1000, UpState) antibody for $1 \mathrm{~h}$ at room temperature or with anti-non acetylated antibody recognised both hystones overnight at $4^{\circ} \mathrm{C}(1: 1000$, UpState). Immunocomplexes were visualized using ECL-Plus system (Amersham).
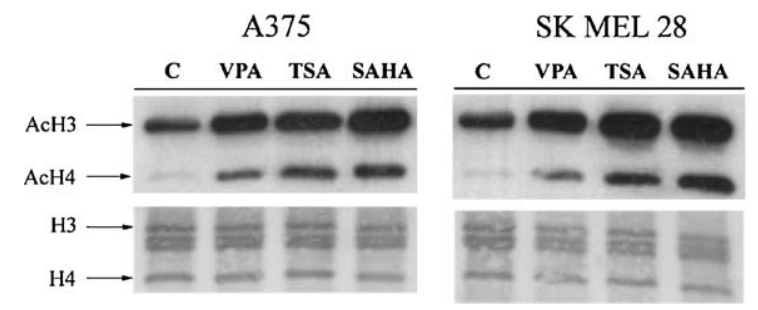

different cell lines can be ascribed to the lack of efficient induction of acetylation.

\section{$\mathrm{Bcl}-2, \mathrm{Bcl} \mathrm{X}_{\mathrm{L} / \mathrm{S}}, \mathrm{Mcl}-1, \mathrm{NOXA}$, survivin and Apaf-1 expression}

As VPA did not affect the proliferative capacity of SK-Mel 28 and WM115 melanoma cells, the differences in pro-

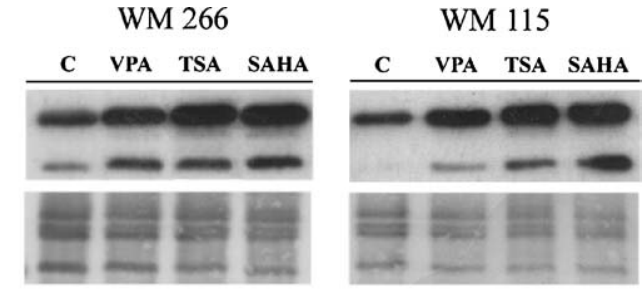

and anti-apoptotic factors between VPA-sensitive and resistant cells were investigated. We focused on $\mathrm{Bcl}-2$, $\mathrm{Bcl}-\mathrm{XL}, \mathrm{Mcl}-1$ and survivin as anti-apoptotic genes and Apaf-1 and Bcl-Xs and NOXA as pro-apoptotic ones. Since SAHA and TSA produced the same effects, only the results obtained with SAHA were presented. For the same reason, only data from one of each VPA-sensitive and -resistant cells, i.e., SK-Mel28 and WM266, were shown below. Using RT-PCR we found that $\mathrm{Bcl}-2$ was not 
Figure 3. Cell lysates were prepared from cells treated with $4 \mu \mathrm{M}$ SAHA for $72 \mathrm{~h}$ or with $1 \mathrm{mM}$ VPA for a week. Proteins $(80 \mu \mathrm{g} / \mathrm{sample})$ were submitted to $15 \%$ SDS-PAGE and blotted onto a PVDF sheet. The membrane was incubated with antibodies directed against Bcl-2 (1:100, Dako), BclX $S_{S / L}$ (1:2000, Pharmingen International) or anti-Apaf-1 (1:1000, Sigma) overnight at $4^{\circ} \mathrm{C}$. Immunocomplexes were visualized using ECL-Plus system (Amersham). In order to check the correct loading, the same sheet was stripped and incubated with anti- $\beta$-actin antibody $(1: 1000,1 \mathrm{~h})$, (data not shown).

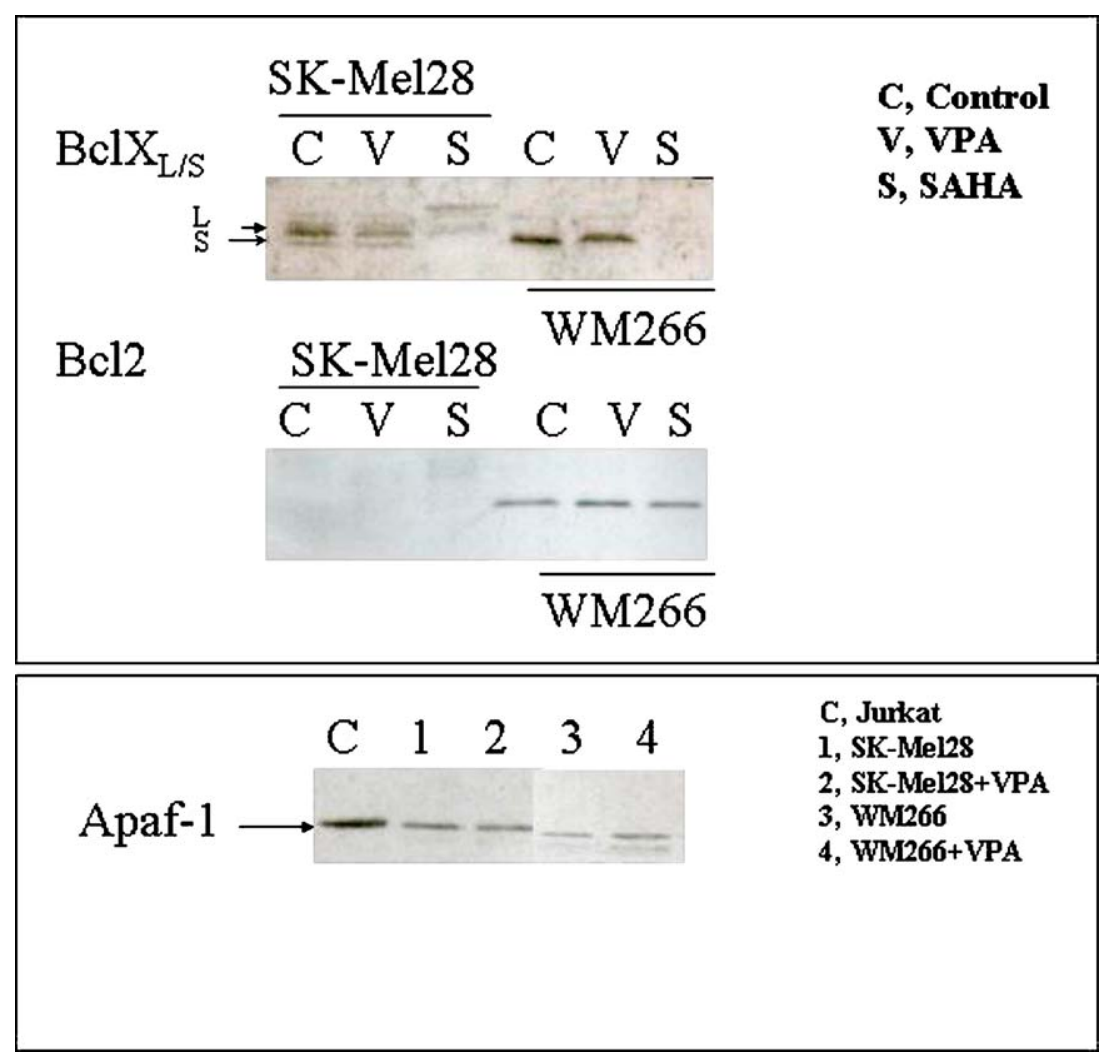

expressed in VPA-resistant melanoma cell lines (Figure 3), while these cells expressed $\mathrm{BclX}_{\mathrm{L}}, \mathrm{Mcl}-1, \mathrm{BclX}_{\mathrm{S}}$ at low level and Apaf-1 (Figure 3). After VPA treatment, we collected the adherent (surviving) cells using trypsin and the expression of anti-apoptotic or pro-apoptotic factors were analysed by Western blotting. The treatment with VPA did not change either the level of expression of Bcl-2 or the level of expression of $\mathrm{BclX}_{\mathrm{L} / \mathrm{S}}$ and Apaf-1 (Figure 3). In contrast, in SAHA treated cells a decrease of both $\mathrm{BclX}_{\mathrm{S}}$ and $\mathrm{BclX}_{\mathrm{L}}$ occurred (Figure 3). Furthermore, SAHA or TSA treatments did not change the basal levels of Apaf-1 (data not shown).

Since both VPA-sensitive cell lines, WM266 and A375, gave the same results, herein, the data of one of the two cell line indifferently are shown. These cells expressed Bcl-2, at high level $\mathrm{BclX}_{S}$ and Apaf-1 (Figure 3). VPA-sensitive cells WM266 expressed Bcl-2, Apaf-1 and relatively high level of Bcl-XS (Figure 3). The treatment with VPA, SAHA or TSA did not change such a basal level except for $\mathrm{Bcl}-\mathrm{XL} / \mathrm{S}$ expression which was decreased by SAHA treatment (Figure 3). In contrast, SAHA treatment did not change Bcl-2 levels (Figure 3).
Finally, the pro-apoptotic gene NOXA, as well as the anti-apoptotic gene survivin, and Mcl-1 were also detected in untreated and treated cells (VPA or SAHA) by RT-PCR (Figure 4). All untreated cells express NOXA and survivin (Figure 4). VPA and SAHA treatments did not modify the basal level of NOXA (Figure 4). Either VPA or SAHA treatments significantly reduced the level of expression of survivin only in VPA-sensitive cells (Figure 4), while, in VPA-resistant cells, an increased level of survivin occurred after VPA treatment (Figure 4). In contrast, Mcl-1, another antiapoptotic factor, was not significantly modulated by HDAC inhibitors (Figure 4).

\section{Levels of TRAIL-R1 and -R2 in VPA-sensitive or -resistant human melanoma cell lines}

Binding of TRAIL to specific receptors (R1 and R2) leads to the recruitment of FAS-associated death domain (FADD), an adaptor molecule that recruits and activates caspase-8. This initiates the caspase cascade that eventually leads to apoptosis through the activation of effector caspases. Figure 5 shows one out of three independent experiments carried out, all giving similar results. VPA 
Figure 4. Total RNA was purified from subconfluent untreated cells or VPA (7 days) or SAHA (72 h) treated ones using the RNeasy Mini Kit from Qiagen. One microgram of total RNA were reverse transcribed and amplified by means of an "Enhanced avian hs RT-PCR" (Sigma) according to the manufacturer's instructions. PCR conditions and primers for NOXA, survivin and Mcl-1 are reported in the Materials and Methods section. As housekeeping gene, GAPDH was used. Densitometric analysis was carried out using ImageMaster software (Pharmacia Biotech).

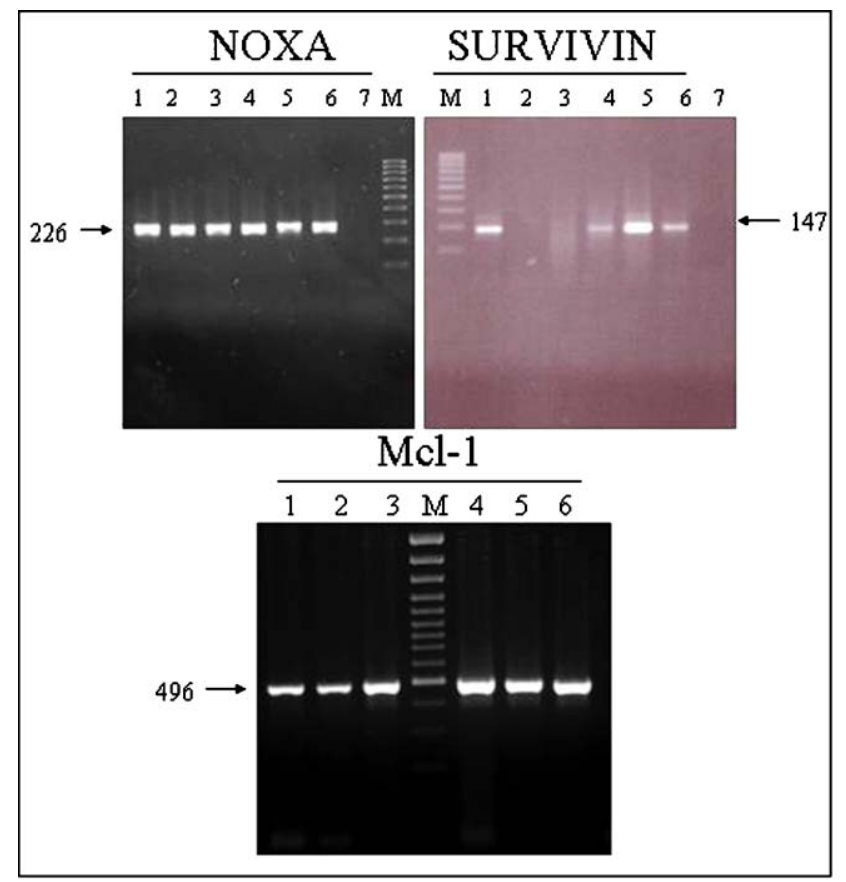

\section{1, WM266 control \\ 2, WM266+VPA \\ 3. WM266+SAHA \\ 4, SK-Mel28 Control \\ 5, SK-Mel28+VPA \\ 6, SK-Mel28+SAHA \\ 7 , Negative control}

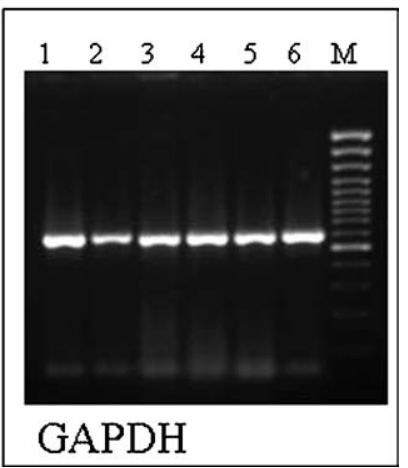

induced an increase of TRAIL-R 1 and -R 2 expression only in VPA-sensitive cells (Figure 5). Similar results were obtained for SAHA from both VPA-sensitive and -resistant cells (only data from VPA-sensitive cells were shown in Figure 5). In contrast, none of the commercially available antibodies work well in western blot, thereby we could not detect the protein level of TRAIL-Rs.

\section{Caspase 8 activation and HDACs treatment}

The effect of HDAC inhibitors on caspase 8 activation is shown in Figure 6. As positive control, Jurkatt cells were treated with anti-Fas antibody concentration which activates caspase 8 and leads to massive apoptosis (90\% of apoptotic cells). Caspase 8 is produced as a proenzyme which, upon receptor aggregation, is proteolytically cleaved into smaller subunits of $40 / 36$ (doublets) and $23 \mathrm{kDa}$ subunits. ${ }^{22}$ These subunits form a proteolytically active heterodimer capable of cleaving other caspase family members as well as substrates such as PARP. Herein we used an antibody which recognises both the proform of caspase $8(55 / 50 \mathrm{kDa}$ doublets) as well as the cleaved forms which migrate at $40 / 36 \mathrm{kDa}$ (doublet) and $23 \mathrm{kDa}$ in SDS-Page. ${ }^{23,24}$ As shown in Figure 6, the treatment with VPA activated caspase 8 only in VPAsensitive cells. In fact, the proteolytically cleaved forms of caspase $8(40 / 36 \mathrm{kDa}$ and $23 \mathrm{kDa})$ appeared after the treatment.

\section{Discussion}

Various melanomas show differences in their aggressive biological behaviour and they also show diverse sensitivity to apoptotic stimuli, e.g. to TRAILmediated apoptosis, ${ }^{15,25} \gamma$-irradiation or chemo- and immunotherapeutics. $^{26}$

VPA is a well-tolerated drug even during long-term treatment and, recently, it is proposed as a useful drug in cancer therapy. ${ }^{10} \mathrm{VPA}$ is known to cause hyper-acetylation of the N-terminal tail of class I HDACs more efficiently than class II enzymes in vitro and in vivo. ${ }^{10}$

In the present paper we studied the effect of different HDAC inhibitors (VPA, TSA and SAHA) in four human melanoma cell lines. We show, for the first time, that VPA differently from SAHA and TSA, acts only on distinct cell lines, producing a peculiar pattern of modulation of apoptotic factors. In fact, two out of four human melanoma cell lines were sensitive to VPA (WM266 and A375 cell lines were sensitive to VPA, while WM115 and SK-Mel28 cells were resistant). In contrast, TSA or SAHA treatments inhibited the proliferation in all the cell lines. 
Figure 5. Total RNA was purified form subconfluent untreated cells or VPA (2, 4, 7 days) (panel A) or SAHA (72 h) (Panel B) treated ones using the RNeasy Mini Kit from Qiagen. One microgram oftotal RNA was reverse transcribed and amplified by means of an"Enhanced avian hs RT-PCR" (Sigma) according to the manufacturer's instructions. PCR conditions and primers for TRAIL-R1 and TRAIL-R2 are reported in the Materials and Methods section. Jurkat cells expressing constitutively TRAIL-R1 and -R2 are used as positive control. As housekeeping gene, GAPDH was used. Densitometric analysis was carried out using ImageMaster software (Pharmacia Biotech). Panel A. Time course of expression of TRAIL-R1 and -R2 in VPA sensitive WM266 cells and in VPA resistant SK-Mel28 cells. Panel B. Densitometric analysis of panel A.
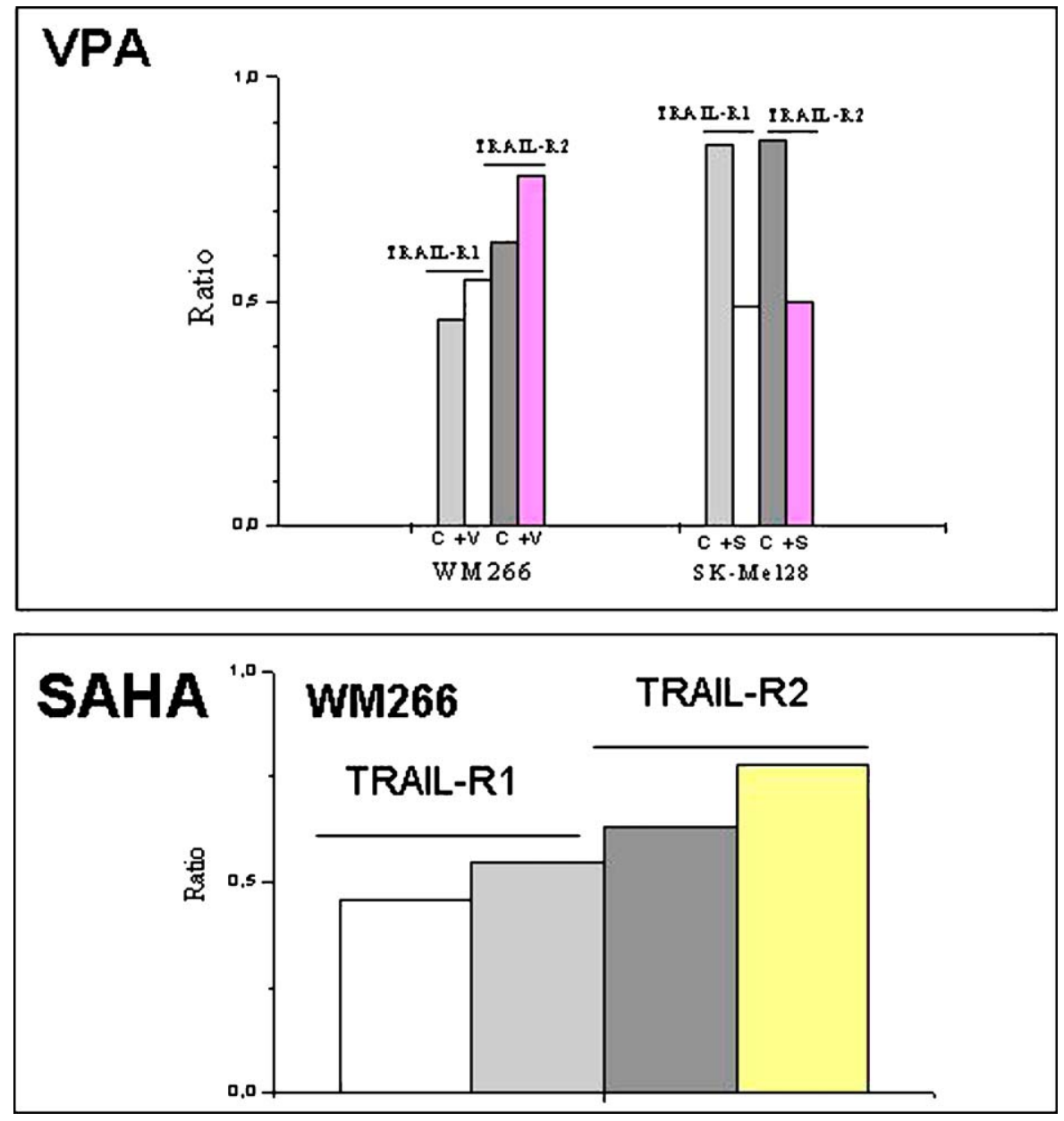

Recently, similar results were obtained in leukemia cells treated with VPA. ${ }^{27}$ However, since the analysis of the status of acetylation of hystone $\mathrm{H} 3$ and $\mathrm{H} 4$ support the inhibitory effect of VPA, we can exclude that the different behaviour of VPA, SAHA or TSA in terms of antiproliferative/apoptotic effect can be ascribed to the lack of efficient induction of HDACs.

Therefore, in order to elucidate the molecular mechanisms triggered by VPA or other HDACs inhibitors such as SAHA, we studied anti- and pro-apoptotic factors such as Bcl-2, BclX $\mathrm{L}$, Apaf-1, BclXs, NOXA, TRAIL-R1 and $-\mathrm{R} 2, \mathrm{Mcl}-1$ and survivin. Mcl-1 was included in our analysis as it is homolog to $\mathrm{Bcl}-2$ and deeply involved in the regulation of apoptosis in hemopoietic cells. ${ }^{28}$ In addition, Mcl-1 is downregulated in hemopoietic cells by activation of the CAMP pathways in relation to cell viability and differentiation. ${ }^{29,30}$ Finally, to better characterize the apoptotic pathway possibly modulated by treatments (i.e receptor-mediated apoptotic pathway) we also examined the possible activation by HDACs inhibitors of caspase 8 .

Firstly, our data demonstrate the baseline differences in pro- and anti-apoptotic factors in VPA-sensitive and -resistant cell lines. VPA-sensitive cells express as antiapoptotic factors Bcl-2, Mcl-1 and survivin and as proapoptotic factors Apaf-1, BclX and NOXA (Table 2). In contrast, the resistant cell lines express as anti-apoptotic factors, $\mathrm{Mcl}-1, \mathrm{BclX}_{\mathrm{L}}$ and survivin and as pro-apoptotic factors, NOXA and BclX and Apaf-1. In the latter no expression of $\mathrm{Bcl}-2$ occurred (Table 2). $\mathrm{Bcl}-2$ expression is commonly found in melanocytes lesions, regardless of their biological behaviour, but the progression of malignant melanoma was shown to be independent of high expression of Bcl2. ${ }^{31,32}$ Moreover, TRAIL-R1, -R2 and Apaf-1 are expressed in all the human melanoma cell 
Figure 6. Cell lysates were prepared from cells treated with $4 \mu \mathrm{M}$ SAHA for $72 \mathrm{~h}$ or with $1 \mathrm{mM}$ VPA for 4 or 7 days. Proteins (80 $\mu \mathrm{g} / \mathrm{sample}$ ) were submitted to $13 \%$ SDS-PAGE and blotted onto a PVDF sheet. The membrane was incubated with anti-caspase 8 (1:2000) overnight at $4^{\circ} \mathrm{C}$. Immunocomplexes were visualized using ECL-Plus system (Amersham). As positive control subconfluent Jurkat cells are treated with anti-Fas antibody for $24 \mathrm{~h}(1 \mu \mathrm{g} / \mathrm{ml})$ and then $80 \mu \mathrm{g}$ of proteins are loaded on 13\% SDS-PAGE gel. Arrows show the procaspase 8 form of $55 / 50 \mathrm{kDa}$ and the proteolytically forms of $45 / 40 \mathrm{kDa}$ and $23 \mathrm{kDa}$.

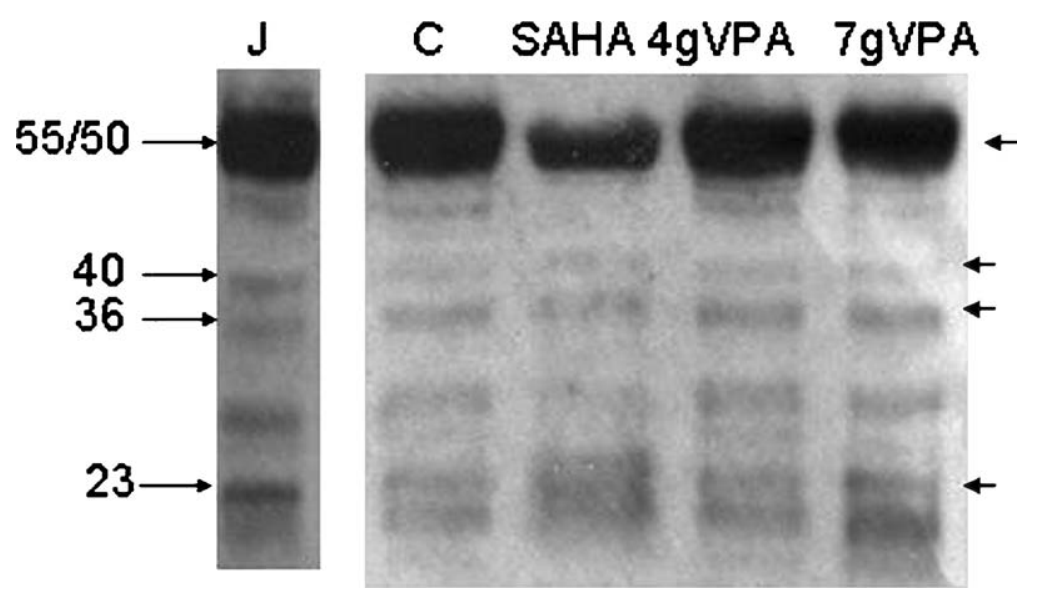

lines analysed, irrespectively of sensitivity or resistance to VPA. Interestingly, in human melanoma cells Mcl-1 is of functional relevance for survival and subject to dual regulation by the MAP-kinase pathway and a pathway involving protein kinase $\mathrm{B} / \mathrm{Akt} .{ }^{33}$ Secondly, VPA or SAHA treatments modulate distinct pro- and anti-apoptotic factors (Table 3). In particular, VPA enhances the level of survivin only in VPA- resistant cells. In the same cells SAHA does not modify survivin levels, but decreased another anti-apoptotic factor, $\mathrm{BclX}_{\mathrm{L}}$, leading possibly the balance versus apoptosis. In contrast, in VPA-sensitive cells, both treatments (VPA or SAHA) decrease the level of survivin. Thereby, the modulation of anti-apoptotic factors such as survivin/BclX $\mathrm{L}_{\mathrm{L}}$ seems to be important for the induction of VPA apoptosis. Recently, an analogue of polyamine was demonstrated to cause rapid apoptosis in human melanoma SK-Mel28 cells degrading survivin. ${ }^{34}$ Accordingly, the attenuation of survivin expression was demonstrated to make human melanomas more suscep- tible to gamma-irradiation. ${ }^{35}$ Down-regulation of survivin was also observed in acute leukaemia cells exposed to the HDAC inhibitor LAQ824. ${ }^{36}$ More recently, the expression of apoptosis-related genes has been evaluated in sentinel lymph nodes from melanoma patients and then correlated to the outcome of patients. ${ }^{37}$ This paper demonstrated that survivin expression correlates with the outcome patients and therefore it was a useful prognostic indicator. ${ }^{37}$ On the other hand, the expression of a phosphorylation-defective survivin mutant triggered apoptosis in several human melanoma cell lines enhancing cell death by antitumor drugs such as cisplatin. ${ }^{38}$ Regarding to Mcl-1, our findings clearly show that VPA does not modify its expression.

Thereby, survivin appears to be the main anti-apoptotic factor modulated by HDAC inhibitors and our data show for the first time that VPA acts on distinct human melanoma cells differently from other HDACs inhibitors. In fact, in addition to hyperacetylation, VPA was

Table 2. Effect of VPA on VPA-sensible and -resistant human melanoma cell lines. $\downarrow$, decrease; -unchanged; $\uparrow$ increase

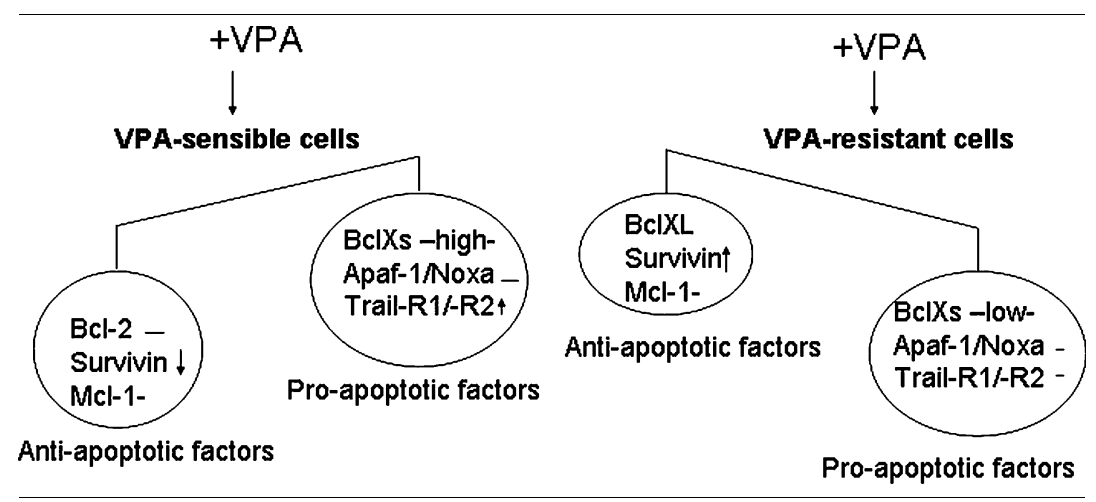


Table 3. Effect of SAHA on VPA sensible and resistant human melanoma cell lines. $\downarrow$, decrease -unchanged; $\uparrow$ increase

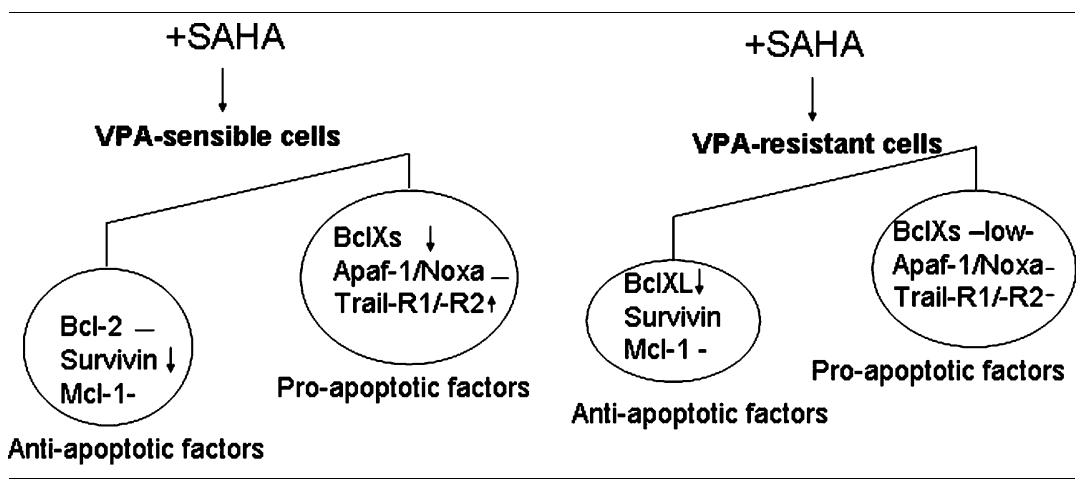

reported to increase DNA binding of AP1 transcription factor, to down-regulate protein kinase $\mathrm{C}$ (PKC) activity, to inhibit glycogen synthase kinase -3 (GSK-3b), and it also was reported to act as negative regulator of wnt signalling pathways. ${ }^{14}$ Therefore, it is tempting to speculate that different intracellular pathways modulated by VPA in distinct melanoma cells, could modify the expression of survivin.

On the other hand, an interesting finding of this study was that VPA affects mRNA levels of TRAIL-R1 and $\mathrm{R} 2$ expression differently in VPA-sensitive or -resistant cells. In fact, VPA treatment induced an increase in both receptors and activation of caspase 8 in VPA-sensitive cells, which, however, was not observed in the resistant cells. This observation suggests that the receptormediated apoptotic pathway may also be involved in VPA triggered apoptosis. These results which are in agreement with recent observations in acute leukaemia cells ${ }^{36}$ support the potential interest of the combination of HDAC inhibitors and TRAIL.

All of all, in view of a new therapeutic approach for melanoma, our results show that a well tolerated drug such as VPA can be effective in inducing cell death on a subset of melanoma, (modulating in particular survivin expression), and that the balance between pro- and antiapoptotic factors in distinct melanomas can account at least in part for the responsiveness to distinct drugs. Therefore, our findings suggest that HDAC inhibitors including VPA, SAHA and TSA may represent a promising therapeutic strategy to treat melanoma.

\section{Acknowledgments}

This work was supported by Ministero della Salute, Ricerca Finalizzata 2002-2004 and Italian Association for Cancer Research (AIRC).

\section{References}

1. Grunstein M. Histone acetylation in chromatin structure and transcription. Nature 1997; 389: 349-352.
2. Butler LM, Agus DB, Scher HI, et al. Suberoylanilide hydroxamic acid, an inhibitor of histone deacetylase, suppresses the growth of prostate cancer cells in vitro and in vivo. Cancer Res 2000; 60: 5165-5170.

3. Richon VM, Webb Y, Merger R, et al. Second generation hybrid polar compounds are potent inducers of transformed cell differentiation.Proc Natl Acad Sci 1996; 93: 5705-5708.

4. Zhou X, Marks PA, Rifkind RA, Richon VM. Cloning and characterization of a histone deacetylase, HDAC9. Proc Natl Acad Sci 2001; 98: 10572-10577.

5. Minucci S, Nervi C, Lococo F, Pelicci PG. Histone deacetylases: A common molecular target for differentiation treatment of acute mycloid leukemias? Oncogene 2001; 20: 31103115 .

6. Kelly WK, O'Connor OA, Marks PA. Histone deacetylase inhibitors: From target to clinical trials. Expert Opinion Invest Drugs 2002; 11: 1695-1713.

7. DiLiberti JH, Farndon PA, Dennis NR, Curry CJ. The fetal valproate syndrome. Am J Med Genet 1984; 19: 473-481.

8. Nau H, Hauck RS, Ehlers K. Valproic acid-induced neural tube defects in mouse and human: Aspects of chirality, alternative drug development, pharmacokinetics and possible mechanisms. Pharmacology Toxicol 1991; 69: 310-321.

9. Loscher W. Valproate: A reappraisal of its pharmacodynamic properties and mechanisms of action. Prog Neurobiol 1999; 58: 31-59.

10. Gottlicher M, Minucci S, Zhu P, et al. Valproic acid defines a novel class of HDAC inhibitors inducing differentiation of transformed cells. EMBOJ 2001; 20: 6969-6978.

11. Phiel CJ, Zhang F, Huang EY, Guenther MG, Lazar MA, Klein PS. Histone deacetylase is a direct target of valproic acid, a potent anticonvulsant, mood stabilizer and teratogen. $J$ Biol Chem 2001; 276: 36734-36741.

12. Warrel RP Jr, He LZ, Richon V, Calleja E, Pandolfi PP. Therapeutic targeting of transcription in acute promyelocytic leukemia by use of an inhibitor of histone deacetylase. $J$ Natl Cancer Inst 1998; 90: 1621-1625.

13. Lampen A, Siehler S, Ellerbeck U, Gottlicher M, Nau H. New molecular bioassays for the estimation of the teratogenic potency of valproic acid derivatives in vitro: Activation of the peroxisomal proliferator-activated receptor (PPARdelta). Toxicol Appl Pharmacol 1999; 160: 238-249.

14. Blaheta RA, Cinatl J Jr. Anti-tumor mechanisms of valproate: A novel role for an old drug. Medicinal Res Reviews 2002; 22: 492-511.

15. Zhang XD, Franco A, Myers K, Gray C, Nguyen T, Hersey P. Relation of TNF-related apoptosis-inducing ligand (TRAIL) receptor and FLICE-inhibitory protein expression to 
TRAIL-induced apoptosis of melanoma. Cancer Res 1999; 59: $2747-2753$.

16. Lowry OH, Rosebrough NJ, Farr AL, Randall RJ. Protein measurement with the Folin phenol reagent. J Biol Chem 1951; 193: 265-275.

17. Laemmli UK. Cleavage of structural proteins during the assembly of the head of bacteriophage T4. Nature 1970; 227: 680-685.

18. Towbin H, Staehelin T, Gordon J. Electrophoretic transfer of proteins from polyacrylamide gels to nitrocellulose sheets: Procedure and some applications. Proc Natl AcSci 1979; 76: 43504354.

19. Zhou Q, Fukushima P, DeGraff W, et al. Radiation and the Apo2L/TRAIL apoptotic pathway preferentially inhibit the colonization of premalignant human breast cells overexpressing cyclin D1. Cancer Res 2000; 60: 2611-2615.

20. Falleni M, Pellegrini C, Marchetti A, et al. Survivin gene expression in early-stage non small cell lung cancer. $J$ Pathology 2003; 200: 620-626.

21. Jansson AJ, Emtering AM, Arbman G, Sun X. Noxa in colorectal cancer: A study on DNA, mRNA and protein expression. Oncogene 2003; 22: 4675-4678.

22. Thome M, Schneider P, Hofmann K, et al. Viral FLICEinhibitory proteins (FLIPs) prevent apoptosis induced by death receptors. Nature 1997; 386: 517-521.

23. Cock JG, Tepper AD, de Vries E, van Blitterswijk WJ, Borst J. $\mathrm{CD} 95$ (Fas/APO-1) induces ceramide formation and apoptosis in the absence of a functional acid sphingomyelinase. $J$ Biol Chem 1998; 273: 7560-7565.

24. Cock JG, Jeanine GR, Tepper AD, de Vries E, van Blitterswilk WJ, Borst J. Common regulation of apoptosis signalling induced by CD95 and the DNA-damaging stimuli etoposide and g-radiation downstream of caspase 3 -activation. J Biol Chem 1999; 274: 14255-14261.

25. Hersey P, Zhang XD. How melanoma cells evade TRAILinduced apoptosis. Nature Reviews Cancer 2001; 1: 142-150.

26. La Porta CAM. Perspectives in melanoma treatment with signal transduction. Current Medicinal Chemistry-Anticancer Agents 2002; 3: 371-385.

27. Kawagoe R, Kawagoe H, Sano K. Valproic acid induces apoptosis in human leukemia cells by stimulating both caspasedependent and -independent apoptotic signaling pathways.
Leukemia Res 2002; 26: 495-502.

28. Ruvolo PP, Deng X, May WS. Phosphorylation of Bcl2 and regulation of apoptosis. Leukemia 2001; 15: 515-522.

29. Myklebust JH, Josefsen D, Blomhoff HK, et al. Activation of the cAMP signalling pathway increases apoptosis in human Bprecursor cells and is associated with downregulation of Mcl-1 expression. J Cell Physiol 1999; 180: 71-80.

30. Townsend KJ, Zhou P, Qian L, et al. Regulation of MCL1 through a serum response factor/ELK-1 mediated mechanism links expression of a vciability-promoting member of the BCL2 family to the induction of hematopoietic cell differentiation. $J$ Biol Chem 1999; 274: 1801-1813.

31. Selzer E, Schlagbauer-Wadl H, Okamoto I, Pehamberger H, Potter R, Jansen B. Expression of Bcl-2 family members in human melanocytes, in melanoma metastases and in melanoma cell lines. Melanoma Res 1998; 8: 197-203.

32. Plettenberg A, Ballaun C, Pammer J, et al. Human melanocytes and melanoma cells constitutively express the $\mathrm{Bcl}-2$ protooncogene in situ and in cell culture. Am J Pathol 1995; 146: 651-659.

33. Selzer E, Hellinger C, Hoeller C, Oberkleiner P, Wacheck V, Pehemberger H, Jansen B. Betulimic acid-induced Mcl-1 expression in human melanoma made of action and functional significance. Mol Med 2002; 8: 877-884

34. Chen Y, Kramer DL, Li F, Porter CW. Loss of inhibitor of apoptosis proteins as a determinant of polyamine analog-induced apoptosis in human melanoma cells.Oncogene 2003; 22: $4964-$ 4972.

35. Pennati M, Binda M, Colella G, et al. Radiosensitization of human melanoma cells by ribozyme-mediated inhibition of surviving expression. J Invest Dermatol 2003; 120: 648-654.

36. Guo F, Sigua C, Tao J, et al. Cotreatment with Histone Deacetylase Inhibitor LAQ824 Enhances Apo-2L/Tumor Necrosis Factor-Related Apoptosis Inducing Ligand-Induced Death Inducing Signaling Complex Activity and Apoptosis of Human Acute Leukemia Cells. Cancer Res 2004; 64: 2580-2589.

37. Gradilone A, Gazzaniga P, Ribuffo D, et al. Survivin, bcl-2, bax and bcl-X gene expression in sentinel lymph nodes from melanoma patients. J Clin Oncol 2003; 21: 306-312.

38. Grossman D, Kim PJ, Schechner JS, Altieri DC. Inhibition of melanoma tumor growth in vivo by surviving targeting. PNAS 2001; 98: 635-640. 